\title{
MODEL PLASTISITAS MOHR-COULOMB, DRUCKER-PRAGER, CAM-CLAY, DAN CAP BERDASARKAN KONSEP CRITICAL STATE
}

\author{
Andrias Suhendra Nugraha \\ Jurusan Teknik Sipil, Universitas Kristen Maranatha \\ J1. Prof. drg. Soeria Sumantri MPH. No. 65, Bandung, 40164 \\ telp. (022) 2012186, fax. (022) 2017622
}

\begin{abstract}
ABSTRAK
Semua jejak lintasan sejarah pembebanan pada tanah akan berakhir dan runtuh menuju pada suatu garis yang dikenal sebagai critical state line. Di luar boundary surface, tidak mungkin dijumpai jejak pembebanan tanah. Jejak lintasan tanah pada umumnya adalah elastoplastis. Jejak pembebanan pada bidang elastic wall hingga interseksi bidang tersebut bidang drained atau undrained merupakan perilaku elastis dari tanah. Keluar dari yield line, perilaku tanah menjadi plastis hingga menuju boundary surface dan berakhir di critical state line. Tulisan ini hendak menjabarkan mengenai beberapa model plastisitas yang dapat digunakan untuk memberi gambaran mengenai fenomena plastis pada tanah. Model yang akan dibahas adalah Mohr-Coulomb, Drucker-Prager, Cam-Clay, dan CAP model. Beberapa parameter, cara memperoleh parameter, serta keuntungan dan kelebihan pada model-model tersebut juga dicoba dijabarkan. Studi kasus dilakukan pada tanah lempung Universitas Kristen Maranatha Bandung dengan data hasil pengujian triaxial compression consolidated undrained. Data hasil penyelidikan tersebut digunakan untuk mendapatkan parameter-parameter tanah yang diperlukan dalam model-model plastisitas yang dibahas, serta memberi keterangan yang diperlukan sebagai interprestasi hasil dari kurva yang dihasilkan.
\end{abstract}

Kata kunci: Critical state line, Mohr-Coulomb, Drucker-Prager, Cam-Clay, CAP

\begin{abstract}
All stress path of the soil will be end and failure occurred at the critical state line. Out of boundary surface, it is impossible to find stress path. In general, soil stress path is elastoplastic. Stress path on elastic wall plane until its intersection, drained and undrained are elastic behavior of the soil. Out of yield line, soil behavior become plastic until reached boundary surface and finally end at critical state line. This paper will describe about plasticity model which is we can used to give a view of plastic phenomena of the soil. The models are Mohr-Coulomb, Drucker-Prager, Cam-Clay and Cap model. Soil parameters, method to predict soil parameters, advantage and disadvantage of the models will be describe too. The case study used clay in Universitas Kristen Maranatha Bandung with triaxial compression consolidated undrained test data. Data from soil exploration is used to have soil parameters which used in plasticity models and curves interpretation.
\end{abstract}

Key words: Critical state line, Mohr-Coulomb, Drucker-Pager, Cam-Clay, CAP

\section{PENDAHULUAN}

Semua jejak lintasan sejarah pembebanan pada tanah akan mengikuti boundary surface, Roscoe dan Hvorslev surface, hingga berakhir runtuh menuju pada suatu garis yang 
dikenal sebagai critical state line. Di luar boundary surface, tidak mungkin dijumpai jejak pembebanan tanah. Boundary surface yang dimaksud, dapat dilihat pada Gambar 1.

Jejak lintasan tanah pada umumnya adalah elastoplastis. Jejak pembebanan pada bidang elastic wall hingga interseksi bidang tersebut bidang drained atau undrained merupakan perilaku elastis dari tanah. Interseksi tersebut dikenal sebagai yield line. Regangan yang terjadi dibawah yield line adalah regangan elastis.

Jika beban dihentikan, regangan akan kembali ke awal tanpa ada perpindahan tetap. Bila jejak lintasan pembebanan keluar dari yield line, perilaku tanah menjadi plastis hingga menuju boundary surface dan berakhir di critical state line. Regangan yang terjadi adalah regangan plastis.

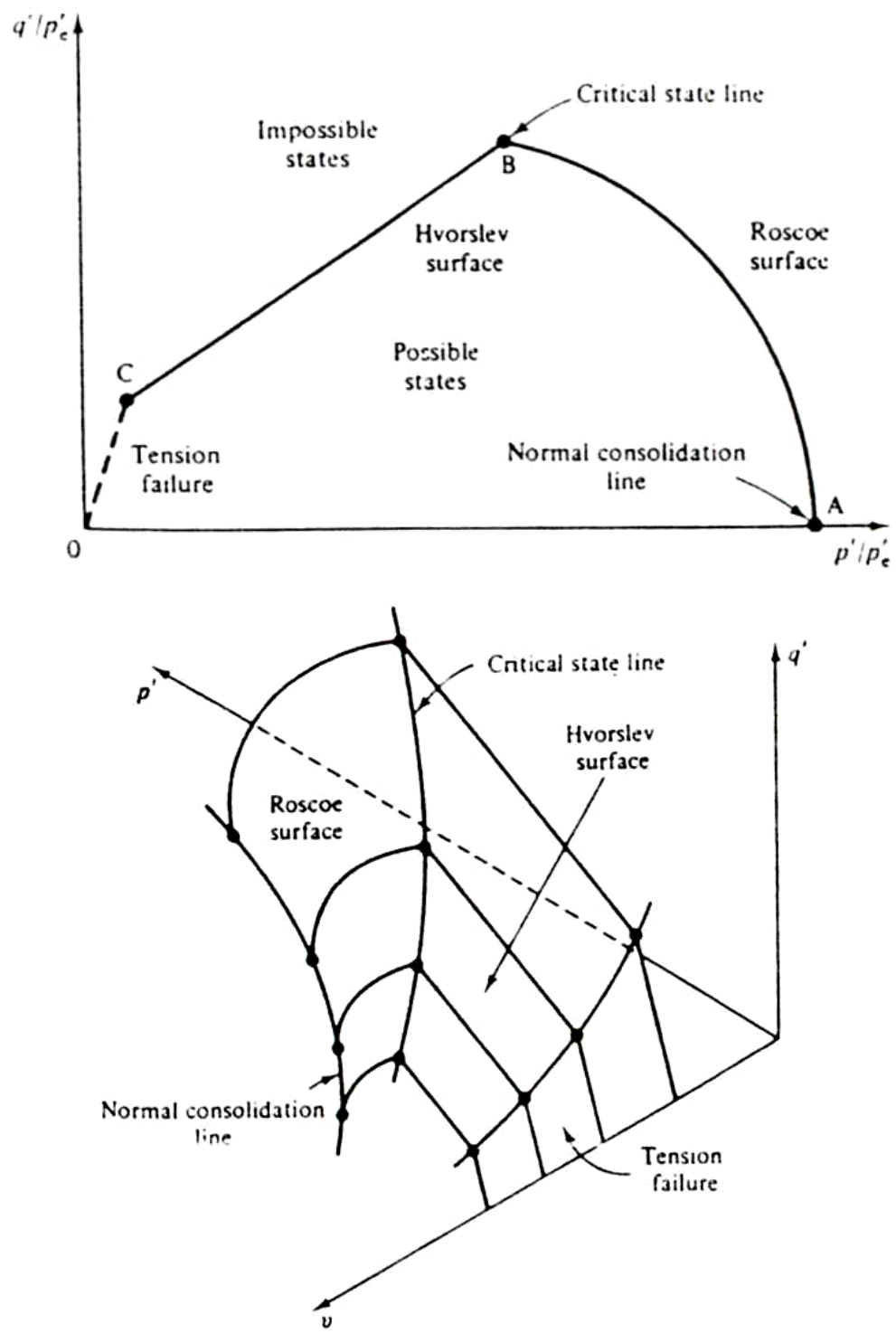

Gambar 1. Roscoe dan Hvorslev Surface 


\section{METODOLOGI}

Tulisan ini hendak menjabarkan mengenai beberapa model plastisitas yang dapat digunakan untuk memberi gambaran mengenai fenomena plastis pada tanah. Model yang akan dibahas adalah Mohr-Coulomb, Drucker-Prager, Cam-Clay, dan CAP model. Beberapa parameter, cara memperoleh parameter, serta keuntungan dan kelebihan pada model-model tersebut juga dicoba dijabarkan.

Kriteria keruntuhan Mohr-Coulomb secara ringkas dapat digambarkan dalam lingkaran Mohr seperti nampak pada Gambar 2. Kekuatan geser pada tanah meningkat seiring dengan meningkatnya tegangan normal pada bidang runtuh,

$\tau=\mathrm{c}+\sigma \tan \phi$
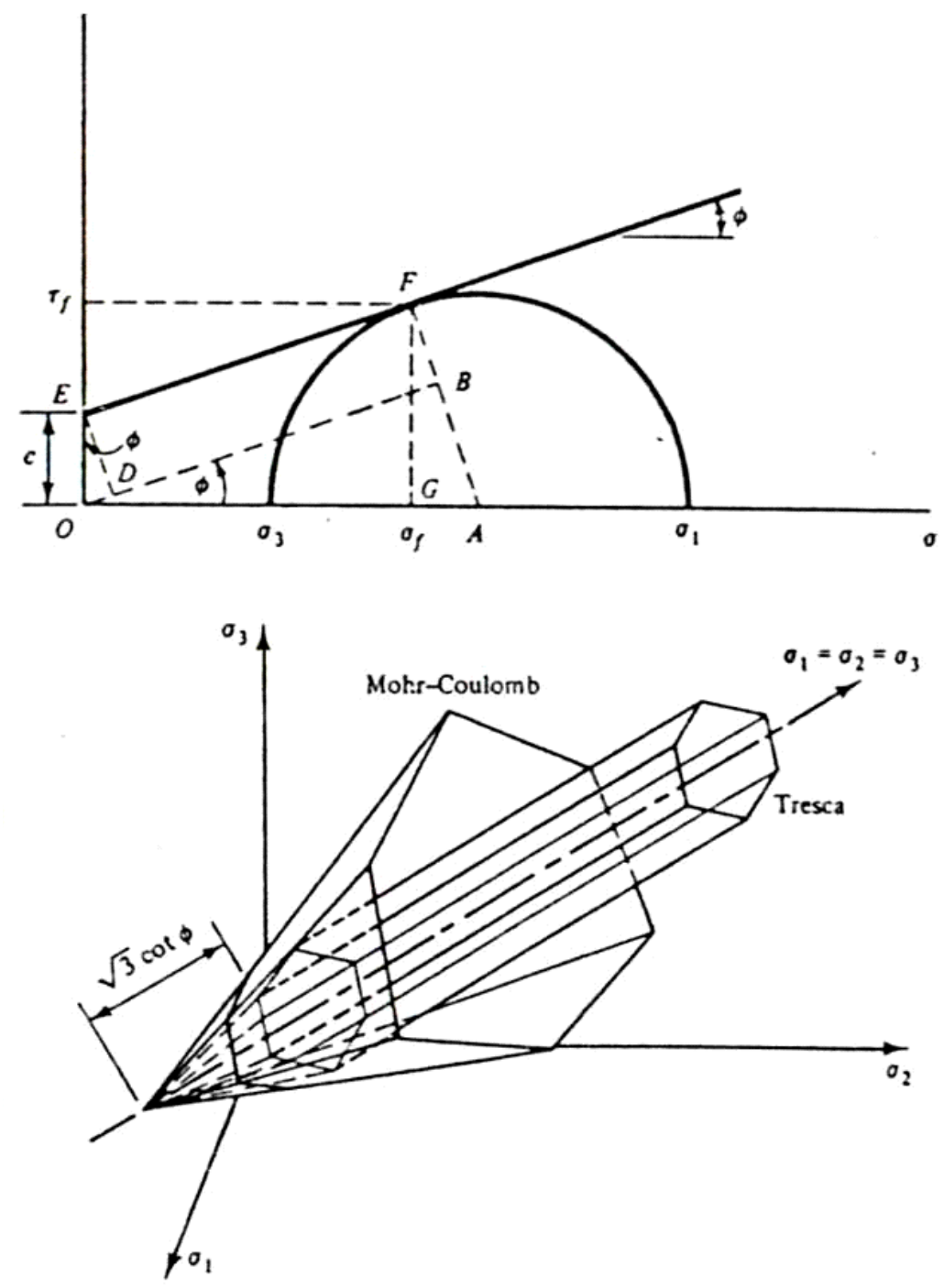

Gambar 2. Model Mohr-Coulomb 
Konsep lingkaran Mohr dapat digunakan untuk menyatakan criteria keruntuhan berdasarkan principal stress. Namun sayangnya, criteria Mohr-Coulomb mengabaikan efek dari intermediate principal stress. Yield strength pada kasus tekan, lebih besar daripada pada kasus tarik. Pada criteria ini, sulit digambarkan suatu state of stress tiga-dimensi yang umum yang dapat didefinisikan oleh 6 komponen vektor tegangan.

Cara memperoleh parameter cukup dengan memperoleh minimum dua hasil pengujian dari conventional triaxial compression test dengan benda uji berbentuk silinder.

Model Drucker-Prager agak sedikit berbeda dengan model Mohr-Coulomb. Perbedaan ini dapat dilihat pada Gambar 3. Secara umum model Drucker-Prager dapat dijelaskan melalui kurva seperti nampak pada Gambar 4. Suatu fungsi leleh, f, dinyatakan sebagai

$$
\mathrm{f}=\left(\mathrm{J}_{2 \mathrm{D}}\right)^{1 / 2}-\alpha \mathrm{J}_{1}-\mathrm{k}
$$

dimana $\alpha$ dan $\mathrm{k}$ adalah parameter material positif, $\mathrm{J}_{1}$ adalah invarian pertama dari tensor tegangan, dan $\mathrm{J}_{2 \mathrm{D}}$ adalah invarian kedua dari tensor tegangan deviatorik.

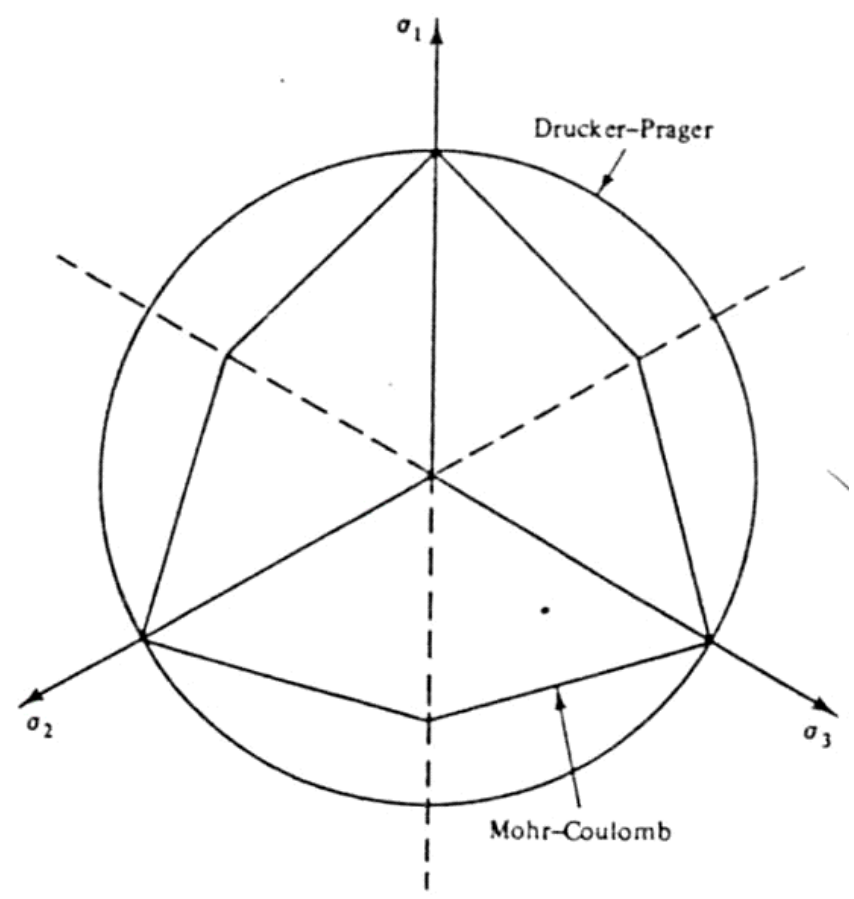

Gambar 3. Perbandingan Mohr-Coulomb dan Drucker-Prager 


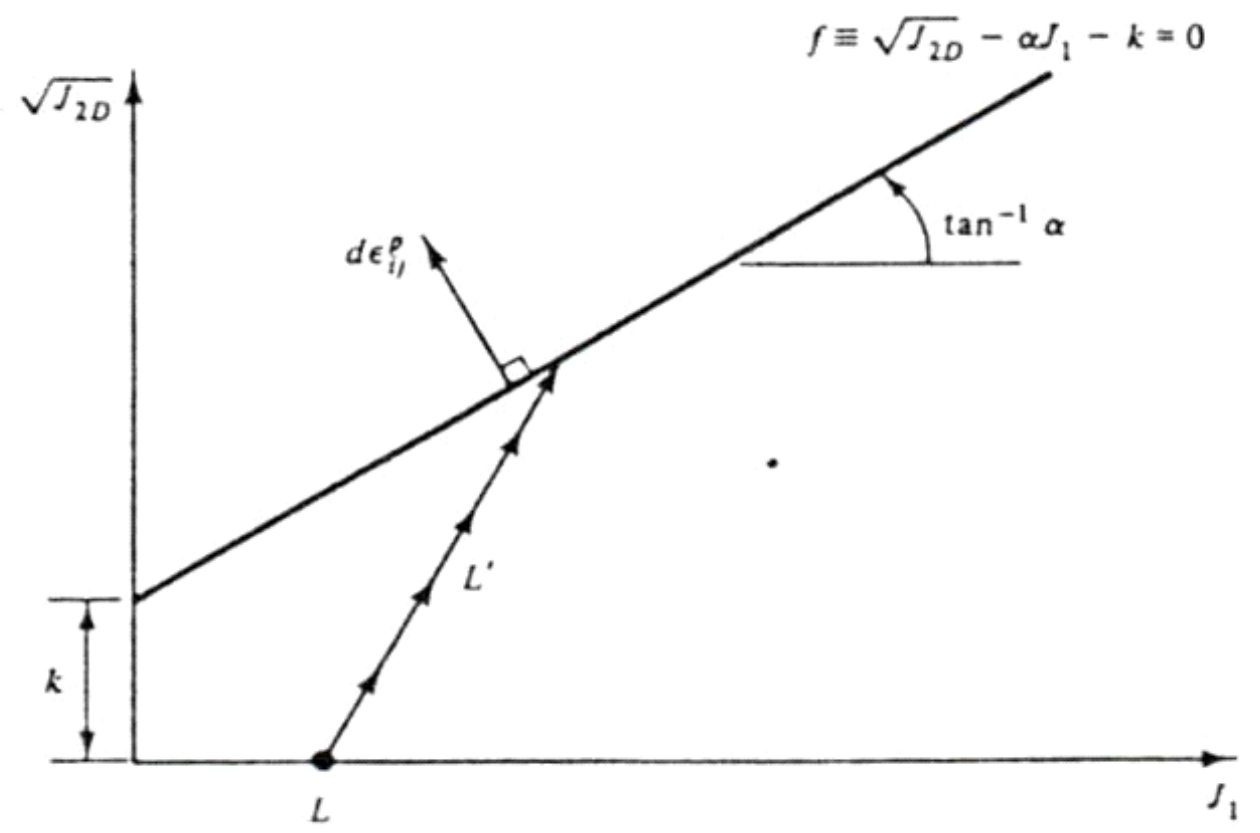

Gambar 4. Drucker-Prager

Keuntungan model Drucker-Prager adalah sudah memperhitungkan seluruh principal stress. Adapun limitasi dari model ini adalah bahwa tidak applicable untuk tanah lempung normally consolidated dan tanah pasir lepas (loose).

Cara mendapatkan parameter ini adalah dengan tes laboratorium dalam bentuk conventional triaxial device, plane strain device, atau truly triaxial device.

Cam-Clay model didasarkan pada konsep critical state. Parameter yang digunakan dalam p, q, dan e. Didefinisikan suatu bidang yang disebut dengan elastic wall, yang merupakan bidang tegak lurus vertikal di atas garis swelling line hingga mencapai permukaan boundary surface, Roscoe dan Hvorslev surface.

Jejak pembebanan pada bidang elastic wall hingga interseksi bidang tersebut bidang drained atau undrained merupakan perilaku elastis dari tanah. Interseksi tersebut dikenal sebagai yield line. Yield line pada kasus model Cam-Clay dapat dilihat pada Gambar 5. Regangan yang terjadi dibawah yield line adalah regangan elastis.

Jika beban dihentikan, regangan akan kembali ke awal tanpa ada perpindahan tetap. Bila jejak lintasan pembebanan keluar dari yield line, perilaku tanah menjadi plastis hingga menuju boundary surface dan berakhir di critical state line. Regangan yang terjadi adalah regangan plastis. 


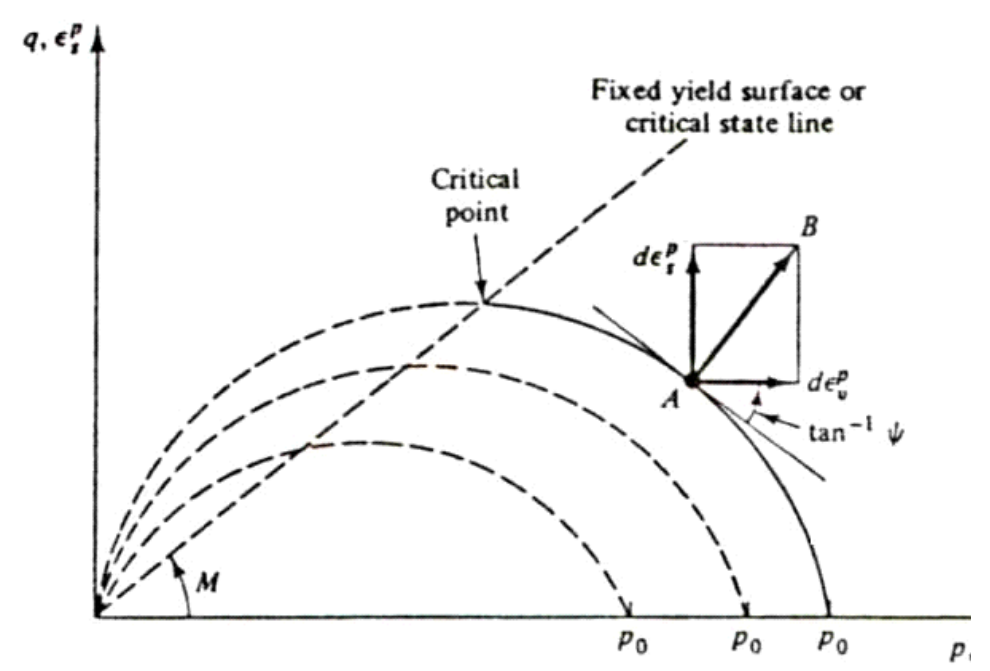

Gambar 5. Cam-clay
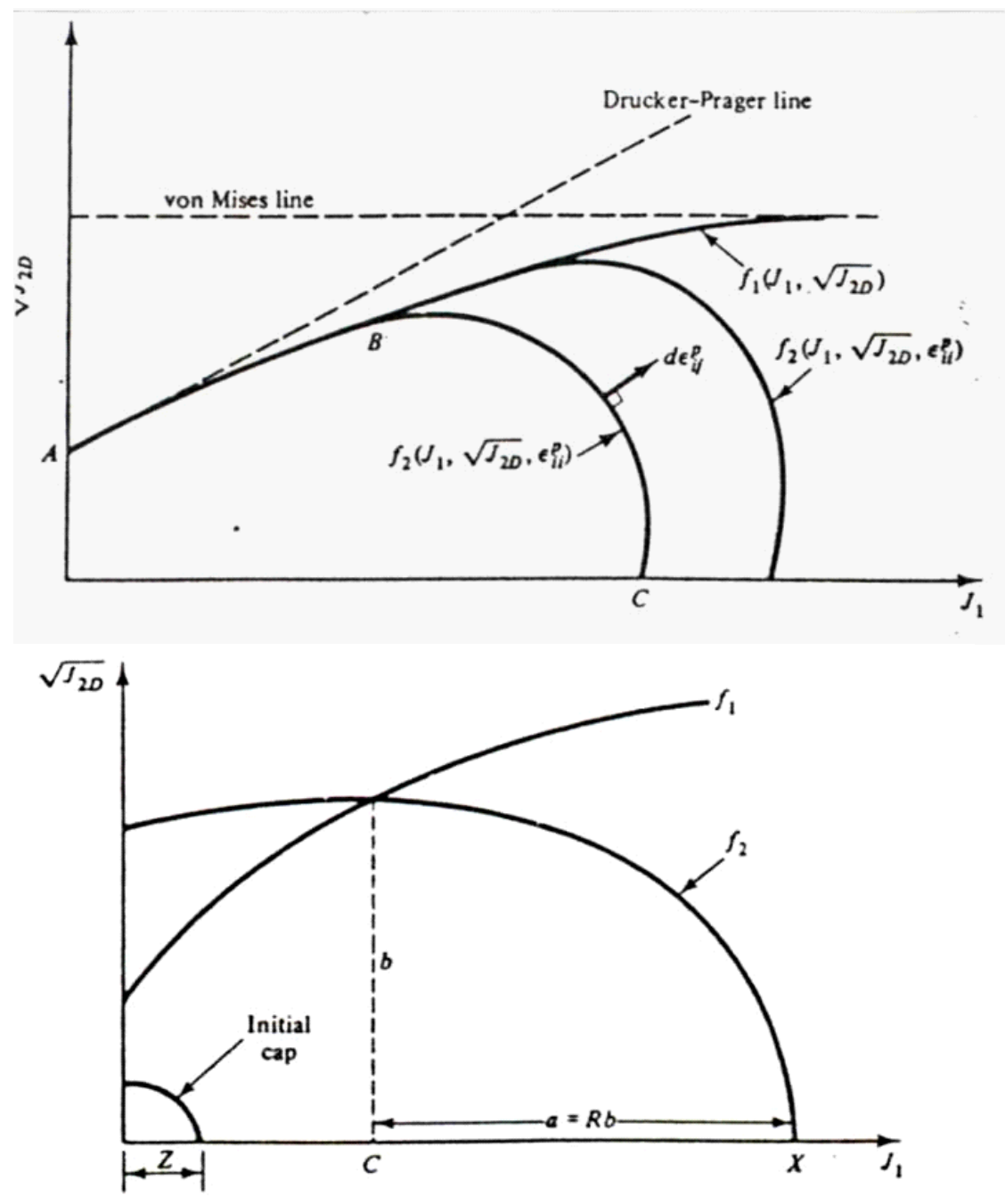

Gambar 6. CAP model 
Model CAP didasari oleh konsep continuous yielding dari tanah, dan dinyatakan dalam state of stress tiga-dimensi, diformulasikan bedasarkan prinsip consistent mechanics. Model CAP diperoleh dari bentuk elliptical yield surface yang menyerupai caps.

Perbedaan antara model Cam-Clay dan CAP dapat dicermati pada Gambar 6. Pada Cam-Clay model, moving cap memainkan peran utama dalam mendefinisikan leleh, dan fixed yield surface digunakan untuk mendefinisikan critical state. Pada model CAP, baik fixed maupun moving surface digunakan untuk mendefinisikan proses kelelehan. Cara mendapatkan parameter adalah dengan melakukan pengujian conventional (cylindrical) triaxial dan conventional consolidation test. Baik model Cam Clay dan CAP, dapat digunakan untuk menggambarkan perilaku material dibawah semua kondisi yang berarti dan semua jejak tegangan.

\section{STUDI KASUS}

Model yang akan dibahas pada studi kasus ini adalah model Mohr-Coulomb dan Drucker-Prager. Studi kasus dilakukan pada sample tanah pada proyek pembangunan gedung kampus Universitas Kristen Maranatha Bandung, Jalan Prof. Drg. Surya Sumantri 65 Bandung. Sampel tanah diperoleh dari titik pengeboran yang nampak pada Gambar 7. Kedalaman tanah diambil 1,45-2.00 m.

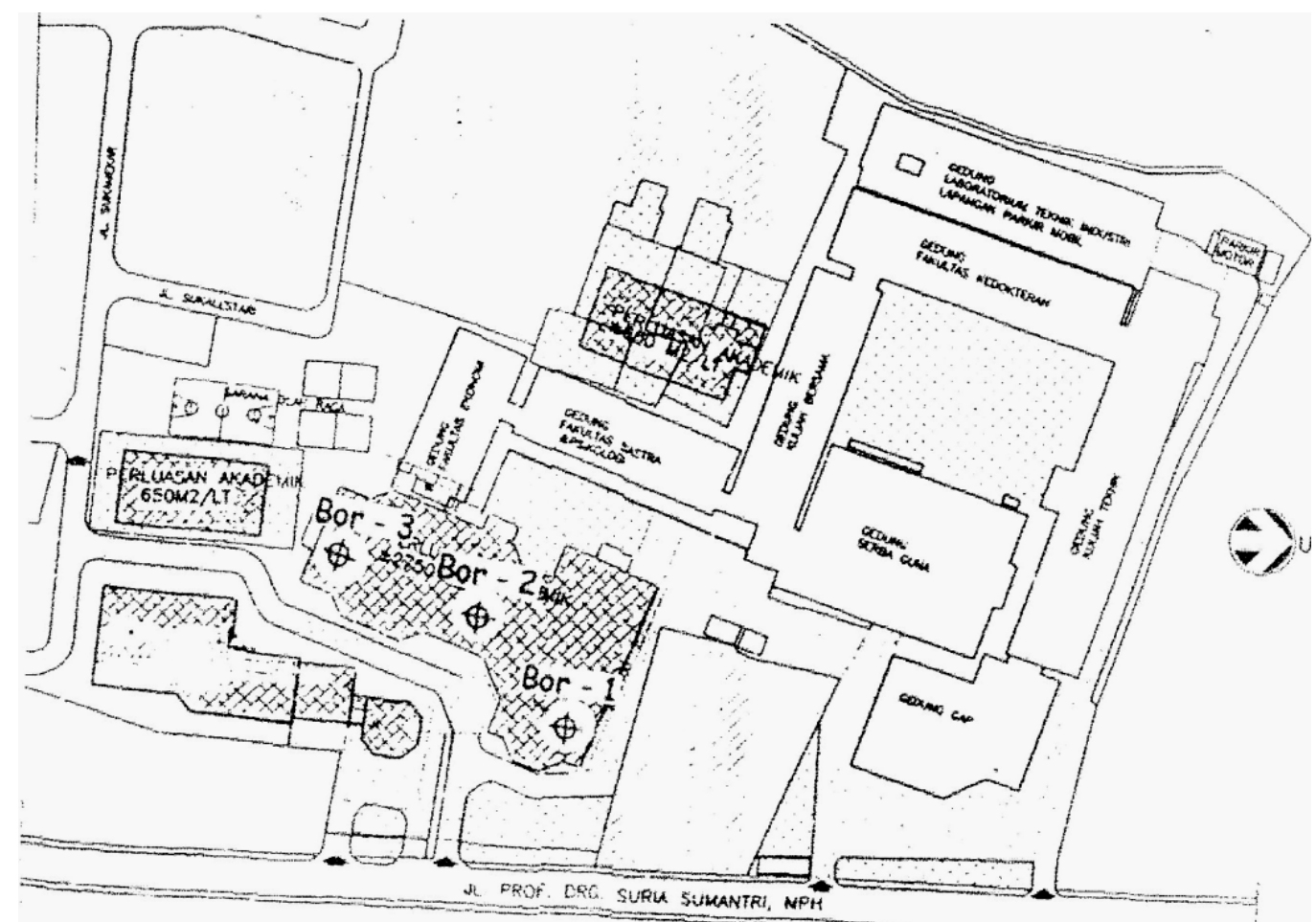

Gambar 7. Lokasi pengeboran pengambilan sampel tanah di UK. Maranatha 
Pengujian geser yang dilakukan adalah uji triaxial consolidated undrained. Data diperoleh dari Laporan Penyelidikan Tanah dari PT. Nasuma Putra, Consulting Engineers yang menangani penyelidikan tanah di proyek tersebut. Hasil pengujian triaxial compression dinyatakan dalam kurva $\left(\sigma_{1}{ }^{\prime}-\sigma_{3}{ }^{\prime}\right)-\varepsilon$ yang ditunjukkan pada Gambar 8 .

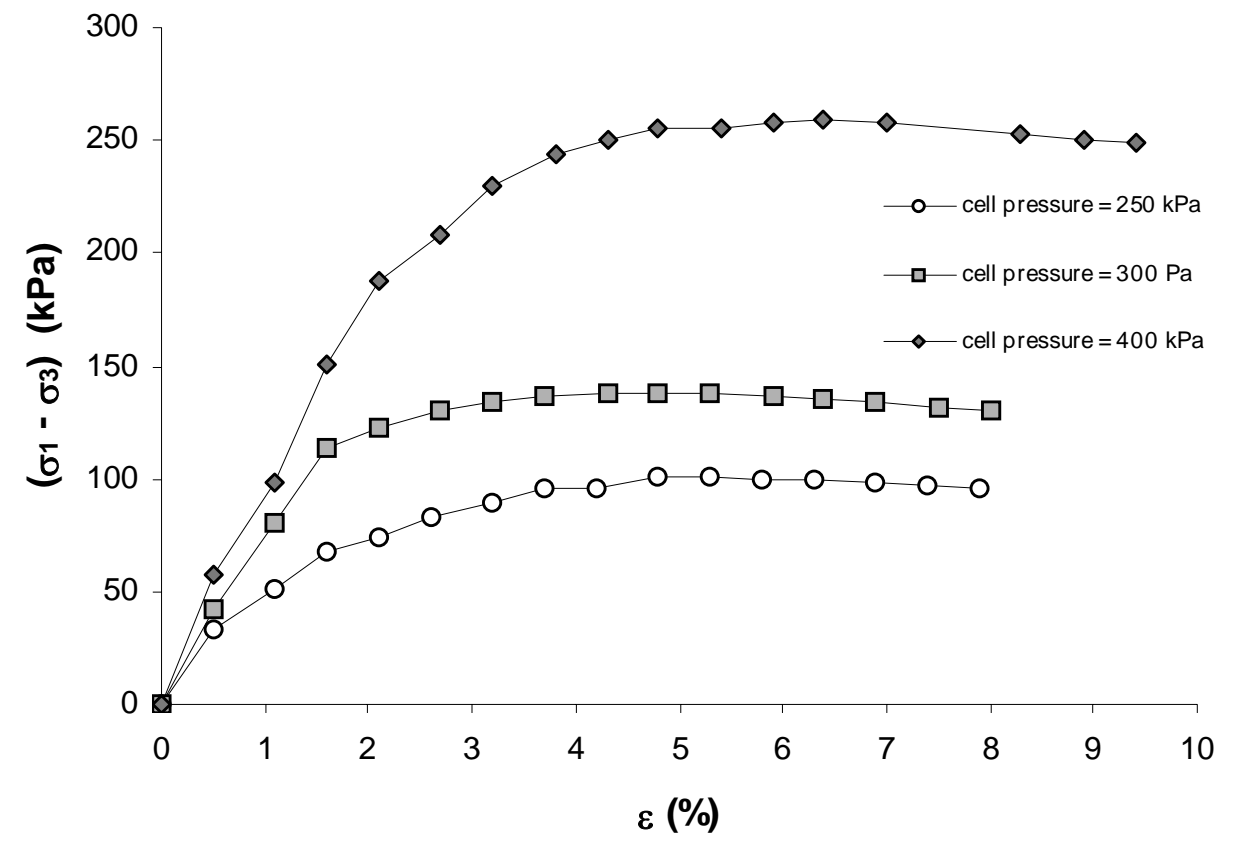

Gambar 8. $\left(\sigma_{1}^{\prime}-\sigma_{3}{ }^{\prime}\right)-\varepsilon$

\section{PEMBAHASAN}

Untuk menggambarkan model Mohr-Coulomb diperlukan parameter tanah yang ditunjukkan pada Tabel 1.

Tabel 1. Parameter tanah untuk penggambaran model Mohr-Coulomb

\begin{tabular}{|c|c|c|c|c|c|}
\hline Test & $\begin{array}{c}\sigma_{3}=\sigma_{\mathrm{c}} \\
(\mathrm{kPa})\end{array}$ & $\begin{array}{c}\left(\sigma_{1}-\sigma_{3}\right)_{\mathrm{f}}=\left(\sigma_{1}{ }^{\prime}-\sigma_{3}{ }^{\prime}\right)_{\mathrm{f}} \\
(\mathrm{kPa})\end{array}$ & $\begin{array}{c}\mathrm{u}_{\mathrm{f}} \\
(\mathrm{kPa})\end{array}$ & $\begin{array}{c}\sigma_{3}{ }^{\prime} \\
(\mathrm{kPa})\end{array}$ & $\begin{array}{c}\sigma_{1}{ }^{\prime} \\
(\mathrm{kPa})\end{array}$ \\
\hline 1 & 250 & 100.61 & 224 & 26.00 & 126.61 \\
\hline 2 & 300 & 138.27 & 249 & 51.00 & 189.27 \\
\hline 3 & 400 & 258.84 & 295 & 105.00 & 363.84 \\
\hline
\end{tabular}

Persamaan yang digunakan untuk mendapatkan parameter pada Tabel 1 adalah sebagai berikut:

$$
\sigma^{\prime}=\sigma-u
$$


Model Mohr-Coulomb dapat dilihat pada Gambar 9. Dari hasil perhitungan diperoleh paramater kuat geser tanah yaitu, $\phi^{\prime}=29^{\circ}$ dan $\mathrm{c}^{\prime}=15 \mathrm{kPa}$.

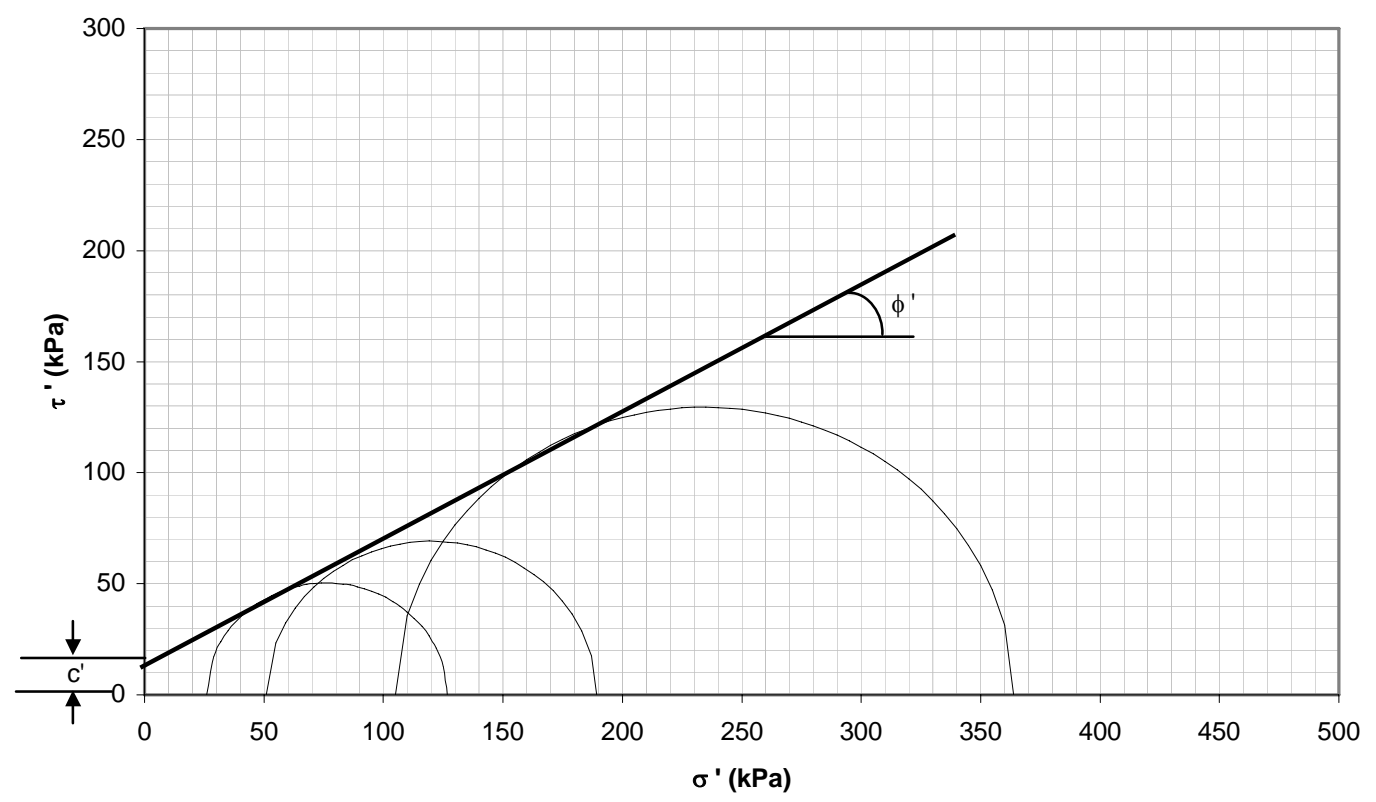

Gambar 9. Model Mohr-Coulomb

Untuk menggambarkan model Drucker-Pruger diperlukan parameter tanah yang ditunjukkan pada Tabel 2.

Tabel 2. Parameter tanah untuk penggambaran model Drucker-Pruger

\begin{tabular}{|c|c|c|c|c|c|c|c|}
\hline Test & $\begin{array}{c}\sigma_{2}=\sigma_{3} \\
(\mathrm{kPa})\end{array}$ & $\begin{array}{c}\left(\sigma_{1}-\sigma_{3}\right)_{\mathrm{f}}=\left(\sigma_{1}{ }^{\prime}-\sigma_{3}{ }^{\prime}\right)_{\mathrm{f}} \\
(\mathrm{kPa})\end{array}$ & $\begin{array}{c}\mathrm{U}_{\mathrm{f}} \\
(\mathrm{kPa})\end{array}$ & $\begin{array}{c}\sigma_{2}{ }^{\prime}=\sigma_{3}{ }^{\prime} \\
(\mathrm{kPa})\end{array}$ & $\begin{array}{c}\sigma_{1}{ }^{\prime} \\
(\mathrm{kPa})\end{array}$ & $\begin{array}{c}\sqrt{\mathrm{J}_{2 \mathrm{D}}} \\
(\mathrm{kPa})\end{array}$ & $\begin{array}{c}\mathrm{J}_{1} \\
(\mathrm{kPa})\end{array}$ \\
\hline 1 & 250 & 100.61 & 224 & 26.00 & 126.61 & 65.00 & 178.61 \\
\hline 2 & 300 & 138.27 & 249 & 51.00 & 189.27 & 72.32 & 291.27 \\
\hline 3 & 400 & 258.84 & 295 & 105.00 & 363.84 & 106.70 & 573.84 \\
\hline
\end{tabular}

Persamaan yang digunakan untuk mendapatkan parameter pada Tabel 2 adalah sebagai berikut :

$$
\begin{aligned}
& J_{2 D}=\frac{1}{6}\left[\left(\sigma_{1}-\sigma_{2}\right)^{2}+\left(\sigma_{2}-\sigma_{3}\right)^{2}+\left(\sigma_{3}-\sigma_{1}\right)^{2}\right] \\
& J_{1}=\sigma_{1}+\sigma_{2}+\sigma_{3}
\end{aligned}
$$

Model Drucker-Pruger dapat dilihat pada Gambar 10. Dari hasil perhitungan diperoleh paramater kuat geser tanah yaitu, $\alpha=8^{\circ}$ dan $\mathrm{k}=40 \mathrm{kPa}$. 


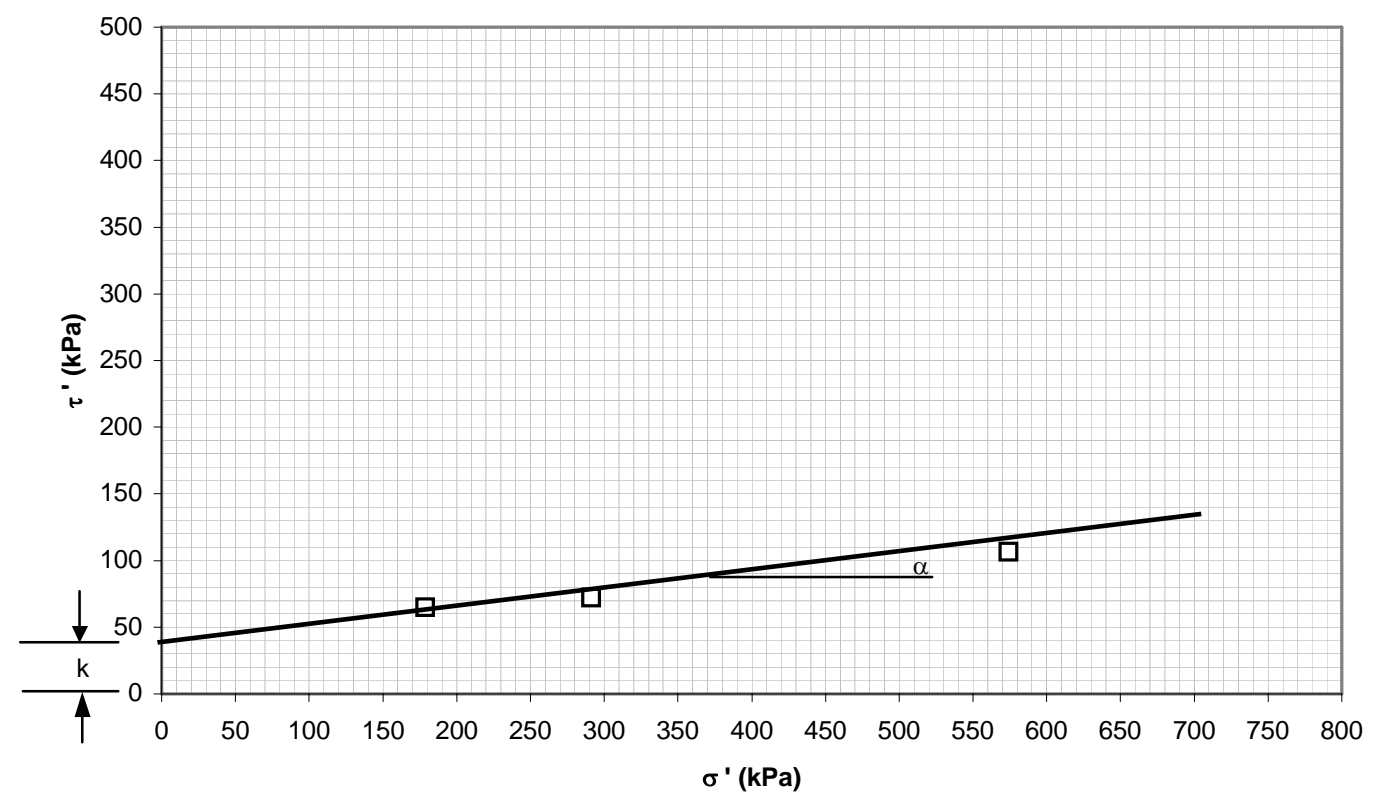

Gambar 10. Model Drucker-Pruger

\section{KESIMPULAN}

Parameter tanah yang diperoleh dari studi kasus pada tanah lempung dengan model Mohr-Coulomb diperoleh parameter kuat geser tanah, $\mathrm{c}=15 \mathrm{kPa}$ dan $\phi^{6}=29^{\circ}$ sedangkan dengan model Drucker-Pruger diperoleh $\mathrm{k}=40 \mathrm{kPa}$ dan $\alpha=8^{\circ}$.

\section{REFERENSI}

1. Atkinson, J.H., Bransby, P.L., (1978), The Mechanics of Soil, An Introduction to Critical State Soil Mechanics, McGraw-Hill, London.

2. Desai, C.S., Siriwardane, H.J., (1984), Constitutive Laws for Engineering Materials,with Emphasis on Geologic Materials, Prentice-Hall, New Jersey.

3. Nasuma Putra, P.T., Consulting Engineers, (2003), Laporan Penyelidikan Tanah Universitas Kristen Maranatha, Bandung. 